\section{Adjudicating science}

\section{Lee Loevinger}

Reference Manual on Scientific Evidence. By William W. Schwarzer et al. Federal Judicial Center, Dolley Madison House, $1520 \mathrm{H}$ Street NW, Washington DC 20005, USA: 1994. Pp. 637. \$25 (pbk).

THE Federal Judicial Center is an agency for policy research and education within the judicial branch of the US government. In 1990, in response to the increasingly complex and esoteric issues coming before federal courts, it decided to prepare a manual to assist judges in managing expert testimony, primarily on issues of science and technology. This volume is the result. As a government publication, the manual is not subject to copyright, and will be made available this month to the principal lawbook publishers, including computer legal networks.

The manual is divided into three parts, the first and third of which each consist of two articles on legal aspects of scientific testimony. The first article discusses the procedural devices by which courts may define and refine technical issues and manage the presentation of expert testimony under the Federal Rules of Civil Procedure. The second article discusses the conditions for admissibility of scientific testimony, which involve both the qualifications of witnesses and the foundation and nature of the testimony. With regard to the latter issue, the decision made in June 1993 by the Supreme Court in the case of Daubert $v$. Merrell Dow Pharmaceuticals established an entirely new set of rules for federal courts, the application of which is still being developed. The discussion of the standards of scientific validity now required for the admissibility of scientific evidence relies largely on cases decided before that date, and so does not add much to the general principles enunciated in the Supreme Court opinion.

The second and principal part of the manual contains seven 'reference guides' detailing the fundamental scope and nature of specific areas of science. The subjects covered are epidemiology, toxicology, survey research, forensic DNA evidence, statistics, multiple regression and the estimation of economic losses in damages awards. Because each article is written by a different author, or set of authors, there is some variation in both style and approach. But the differences are not as great as might be expected in an anthology: each guide has a common framework, with an outline preceding the text, which in turn is divided into sections on issues or subjects peculiarly relevant to

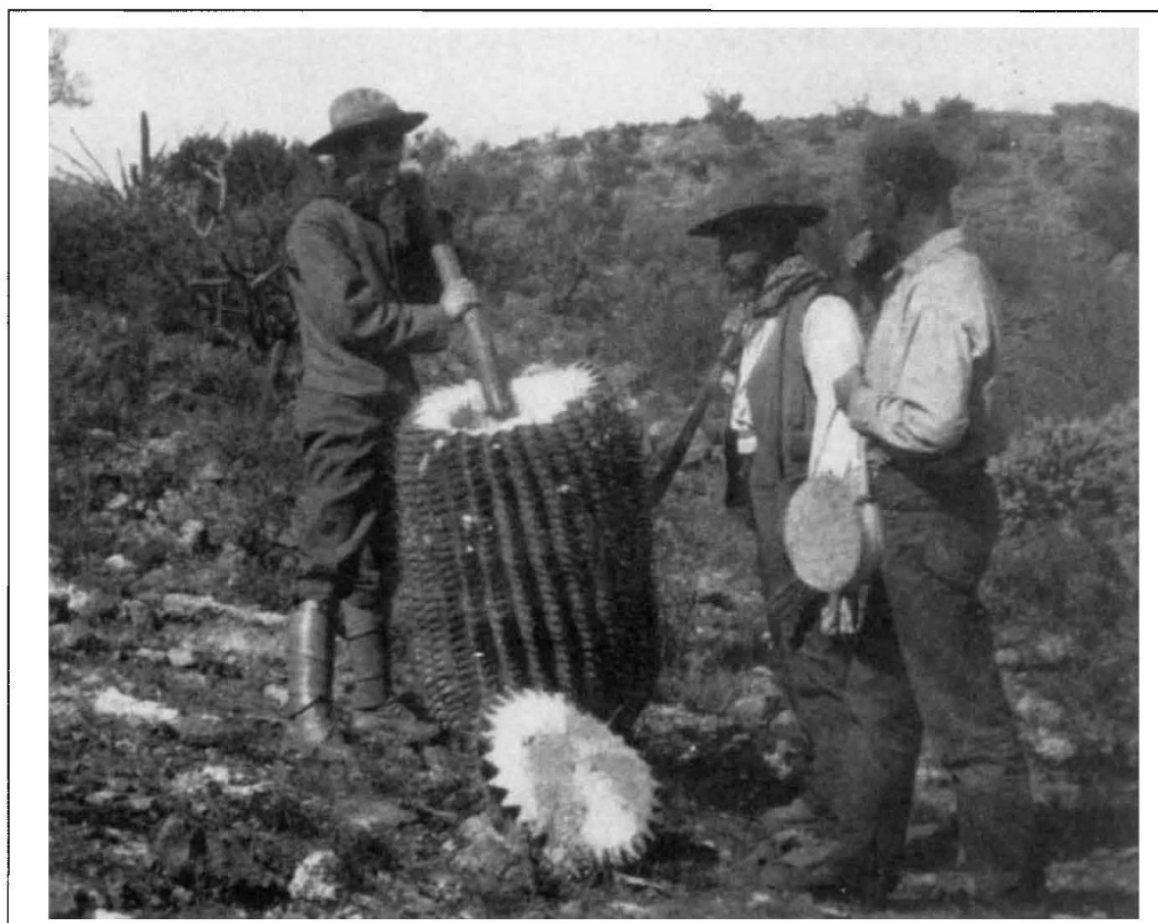

Members of a 1907 expedition to the Piñacate desert region of northern Sonora, Mexico, extract water from a cactus. From Two Eag/es/Dos Aguilas, with photographs by Tupper Ansel Blake and text by Peter Steinhart. For details see page 114

the field; substantial cross-referencing; jargon expounded in reasonably comprehensible language; a glossary that defines the technical patois of the field; and a bibliography of additional reference sources.

The seven guides do not, and could not, attempt to make experts out of the reader; but a diligent reader will be educated sufficiently to converse intelligently with an expert in a particular field and to ask questions that would determine the validity of the expert's testimony. Indeed, much of each guide consists of an explanation of the limitations of expertise in the field, and all are strictly expository rather than anecdotal or philosophical.

As might be expected, a common theme is statistics, which are used in most areas of empirical science. Correspondingly, the longest guide is given over to this subject, and is supplemented by a comprehensive glossary of terms and by another article that illustrates and explains in mathematical detail the statistical process of multiple regression. These sections should be useful to anyone interested in any field of science or technology.

The third part of the manual consists of two articles on special procedures that may aid the consideration of scientific evidence by a federal court. One reports the results of a study by the Federal Judicial Center of court-appointed experts acting under rule 706 of the Federal Rules of Evidence. This permits a federal judge to appoint a presumably impartial expert in a case appearing to require such a procedure. This authority has been used infrequently but successfully in a few cases.
The last article describes a similar study of the power of federal judges to appoint a special master (or referee) under Federal Rule of Civil Procedure 53 to report on a particular aspect of a complex case. This power, too, is rarely used, although it is potentially useful.

The introductory and concluding articles are specifically oriented toward trials in federal courts under existing rules, and will be of interest primarily to federal judges and trial lawyers. These do not have accompanying glossaries. But the seven substantial guides that deal with areas of science relevant to contemporary legal problems will be of interest to anyone who seeks information about the subjects covered. They do not make for particularly easy reading, but all of them are illuminating; the text and the glossary will help in understanding not only testimony but also other technical treatises in the field.

The manual does not cover all types of scientific data that may be used in legal proceedings. Many subjects, such as physics, chemistry and psychiatry, are not included; but future, and no doubt expanded, editions are planned. The scientific expositions provide more questions than answers. In both science and law, however, the first step toward knowledge is to ask the right questions; and in this respect the manual will provide invaluable assistance.

Lee Loevinger is at Hogan and Hartson, 555 Thirteenth Street NW, Washington DC 20004, USA. 